\title{
EXPERIMENTAL STUDY OF THERMAL PERFORMANCE ENHANCEMENT OF A FLAT PLATE SOLAR AIR HEATER USING OPTICAL MEASUREMENT TECHNIQUE
}

\author{
Santosh Vyas ${ }^{1}$, Dr. Sunil Punjabi ${ }^{2}$ \\ ${ }^{1}$ Associate Professor, Department of Mechanical Engineering, MITS, Ujjain, MP, India \\ ${ }^{2}$ Associate Professor, Department of Mechanical Engineering, UEC, Ujjain, MP, India
}

\begin{abstract}
Experimental test set up at laboratory scale was developed for thermal performance testing of flat plate solar air heater with artificial solar radiation intensity; $600 \mathrm{~W} / \mathrm{m}^{2}$. A test cell of size $1 \mathrm{~m} \times 0.5 \mathrm{~m} \times 0.1 \mathrm{~m}$ was fabricated. Three configurations namely (i) plane absorber under natural convection (ii) Inclined Vporous ribs with conducting side walls under natural convection and (iii) Former under forced convection were tested. Performances of these designs have been analysed on the basis of thermal efficiency and thermal gradient in normal to the base. Thermal gradient was determined by optical beam deviation method using a coherent light source namely 10mW He-Ne laser. Temperature sensors (RTD, PT-100) were also used to validate the optical results of thermal gradient. The overall thermal efficiencies of these configurations are found as $14.91 \%, 19.93 \%$ and $31.6 \%$ respectively. Thermal gradient has been found to be reduced with performance enhancement.
\end{abstract}

\section{KEYWORDS}

Solar air heater, Laser beam deviation, Thermal gradient, Overall thermal efficiency.

\section{INTRODUCTION}

Flat plate solar air heaters are generally used for space heating and drying processes of agricultural products, herbs, clothing etc. This system has an important space among solar thermal systems because of economical use of materials. A solar air heater has poor heat transfer between absorber plate and the air which results in major heat losses to the environment which ultimately results in low thermal efficiency of such thermal systems. N. Moummi et al. [1] studied the effect of rectangular plate fins set perpendicular to the air flow field in solar air heater. The air is made to flow out through the interstices between fins; this permits an appropriate distribution of the fluid and reduces the dead zones. M.A. Karim and M.N.A. Hawlader [2] performed an experimental investigation of three designs of solar air collectors, namely flat plate, finned and V-corrugated for achieving an efficient design of air collector suitable for a solar dryer. Results show that the V-corrugated collector has 7-12\% higher efficiency than flat plate collectors. The efficiency of all three air collector designs is found to be function of air mass flow rate. Efficiency is found to be increased with mass flow rate and tends to saturate at a flow rate of $0.056 \mathrm{~kg} / \mathrm{m}^{2} \mathrm{~s}$. There are various factors affecting the solar collector thermal performance, e.g. collector geometry, type of absorber surface, air velocity, top glass cover plate etc. Increase in the absorber area or fluid flow heat-transfer area will tend to improve the heat transfer to the flowing 
air on one hand and will also demand additional power consumption to pump the air flow crossing the collector.

\section{Nomenclature}

\begin{tabular}{|ll|}
\hline$q$ & Convective heat flux, $\mathrm{W} / \mathrm{m}^{2}$ \\
$h$ & Convective heat transfer coefficient, $\mathrm{W} / \mathrm{m}^{2}{ }^{\circ} \mathrm{C}$ \\
$T_{s}$ & Surface temperature, ${ }^{\circ} \mathrm{C}$ \\
$T_{a}$ & Ambient air temperature, ${ }^{\circ} \mathrm{C}$ \\
$k$ & Thermal conductivity, $\mathrm{W} / \mathrm{m}{ }^{\circ} \mathrm{C}$ \\
$n$ & Refractive index \\
$\rho$ & Density of air, $\mathrm{kg} / \mathrm{m}^{3}$ \\
$\Delta y$ & Laser beam deviation, $\mathrm{mm}$ \\
$L$ & Laser beam path length, $\mathrm{mm}$ \\
$\eta$ & Overall thermal efficiency $=\frac{m c_{p}\left(T_{o}-T_{i}\right)}{I A_{c}} \times 100 \%$ \\
& \\
$T_{o}$ & Outlet temperature of air, ${ }^{\circ} \mathrm{C}$ \\
$T_{i}$ & Air inlet temperature, ${ }^{\circ} \mathrm{C}$ \\
$m$ & Mass flow rate of air, $\mathrm{kg} / \mathrm{sec}$ \\
$c_{p}$ & Specific heat of air, $\mathrm{J} / \mathrm{kg}{ }^{\circ} \mathrm{C}$ \\
$I$ & Intensity of simulated solar radiation, $\mathrm{W} / \mathrm{m}^{2}$ \\
$A_{c}$ & Top cover collector area of solar air heater, $\mathrm{m}^{2}$ \\
\hline
\end{tabular}

A number of efforts have been applied in the last 30 years to improve the thermal performance of flat plate solar air heaters by redesigning air channel depth with respect to its length or width; Foued Chabane et al. [3]. Several techniques for enhancement of thermal performance have been proposed and tested by researchers. Most of the testing methods applied are intrusive in nature, in which probes are inserted in the flow field. Measurements in such cases are possible only when it leads to distortion in flow field. Non-intrusive optical methods like interferometry, schlieren photography and shadowgraphy are more effective in obtaining accurate results, owing to absence of distortions in the thermal flow field established inside the test cell. In this approach no sensor or probe is inserted in the thermal flow field rather an optical beam is projected to span the flow field without any distortion and deviation in the results.

In the present work a non intrusive techniques has been used for thermal performance testing of solar air heater. Rajendra Karwa et al. [4] have conducted a comparative study on different types of roughness geometries proposed for solar air heater ducts by researchers. Study shows that the integral chamfered with groove roughness is the most effective one. Vishvajeet Singh Hans et al. [5] investigated heat transfer and friction characteristics of a multiple V-rib roughness on solar air heater performance. Aluminium wires were used for producing roughness on the underside of the absorber plate. The thermal performance of multiple V-rib roughened solar air heaters is found to be more effective than that of single V-rib roughened solar air heater. Significant enhancement in thermo hydraulic performance in multiple V-ribs solar air heater has been reported. Prabha Chand and S.P. Sharma [6] have derived a theoretical model for air temperature rise and efficiency to investigate the thermal performance characteristics of solar air heater having wavy fins over absorber plate. The impact of fin spacing, area enhancement factor and mass flow rate on thermal performance has been analysed and results are compared between finned and plane absorber. Thermal performance of flat-plate solar air heaters is considerably enhanced by wavy fins on the absorber plate and this enhancement is also a strong function of area enhancement factor, fin spacing and air mass flow rate. An enhancement in thermal efficiency of $43 \%$ and $61 \%$ has been 
reported at mass flow rate of $0.0111 \mathrm{~kg} / \mathrm{s}$ while the fin spacing reduces from $4.0 \mathrm{~cm}$ to1.0cm.Turhan Koyuncu [7] analysed and tested six different designs of natural circulation air heating solar collectors for their thermal performance. Each collector is mainly consisted of a hardboard frame, hardboard insulation, absorbing surface made of black coated aluminium sheet, clear plastic glazing and vent holes. Among six designs the test cell with the single plastic glazing, black painted flat plate absorber and front-pass was found to be most efficient. Hikmet Esen [8] has performed an experimental study of novel type flat plate solar air heater with numerous obstacles and without obstacles. In this analysis it was found that, increase in the available heat-transfer area can be achieved if air flows simultaneously and separately over and under the obstacle absorbing plates instead of only flowing either over or under it, resulting in increased collector efficiency. Foued Chabane et al. [9] conducted an experimental research on thermal performance of a single pass solar air heater attached with fins. Longitudinal fins have been used on lower side of the absorber plate to enhance the heat exchange and render uniform flow fluid in the channel. Experiments have been performed for air mass flow rate of $0.012 \mathrm{~kg} / \mathrm{s}$. Maximum efficiency of $40.02 \%$ was attained with five longitudinal fins for the air mass flow rate of $0.012 \mathrm{~kg} / \mathrm{s}$. Arun Venu et al. [10] have introduced porous medium in thermal flow field of solar collector to improve the thermal performance. The selected solar heater can simultaneously be used for heating air and water using incident solar radiation. The porous matrix is mounted on lower side of the absorber plate of the collector. Comparative study of proposed dual purpose solar collector and existing design clearly shows the benefits of porous medium in terms of enhanced thermal performance. Ben Slama Romdhane [11] has studied the hydrodynamic effect of obstacles or baffles in creation of turbulence in the air channels of solar air heater.

factors, such as the obstacles of absorber plate and the air mass flow rate are analysed. Thermal gradient profile at a selected section inside the solar air heater was obtained optically using $10 \mathrm{~mW}$ He-Ne laser beam (coherent source) and by RTD-PT100 temperature sensors.

\section{FUNDAMENTALS OF SOLAR AIR HEATER TESTING}

The theory of solar air heater testing is as follows; H. P. Garg and J.Prakash [12]. In indoor testing arrangement solar air heater is tested under artificial and constant solar radiation intensity. In the experimentation, solar air heater is brought in steady state heat transfer condition by ensuring insignificant variations in inlet and outlet air temperatures and constant air velocity. The overall thermal efficiency is computed by measuring solar radiation intensity, inlet and outlet temperatures and air velocity as given below.

$$
\eta=(\text { Energy received by air } / \text { Heat input })=\frac{m c_{p}\left(T_{o}-T_{i}\right)}{I A_{c}} \times 100 \%
$$

where,

Mass flow rate $(m)=\rho a V$

$a=$ Air flow area $\left(m^{2}\right)$

$V=$ Air velocity $(\mathrm{m} / \mathrm{sec}$. $)$

A conventional flat plate solar air heater of solar dryer has been tested under natural solar radiation for thermal efficiency using above mentioned mathematical method in order to validate the proposed testing procedure which has been applied in this research work. This efficiency has been found around $10 \%$ which is very much closed to claimed value for tested solar air heater. 


\section{DESCRIPTION OF EXPERIMENTAL TEST SET UP}

A laboratory scale experimental test set up (figure 1) was installed for testing of flat plate solar air heater test cell in the lieu of applying concept of testing solar application with indoor simulated environment from investigation suggested by S.C. Solanki et al. [13] for testing of photovoltaic (PV/T) air collectors. Schematic view of test cell is shown in figure 2 . The test set up mainly consists of a rectangular box of $18 \mathrm{~mm}$ thick plywood with inner dimensions of $1 \mathrm{~m} \times 0.5 \mathrm{~m} \mathrm{x}$ $0.1 \mathrm{~m}$. The base of the box is lined with $1 \mathrm{~mm}$ thick blackened aluminium sheet. Test cell is covered at the top with $5 \mathrm{~mm}$ thick toughened plain transparent glass. Toughened glass has ability to encounter hot environment of around $100^{\circ} \mathrm{C}$ without mechanical failure. Atmospheric air will made to flow through the channel between transparent glass and absorber surface. Side walls were not covered with aluminium sheet during initial experiments in order to achieve adiabatic conditions at all the sides and to observe the effect of base only. Rectangular ports two for air inlet of size $76 \times 41 \mathrm{~mm}^{2}$ and two for air outlet of size $130 \times 73 \mathrm{~mm}^{2}$ are provided. A pair of rectangular ports $50 \mathrm{~mm}$ wide is also given on longer side walls for mounting optical windows at a distance of $31 \mathrm{~cm}$ from the inlet air ports for projecting laser beam in a direction parallel to the shorter side wall of the heater during the experimentation for determining thermal gradient.

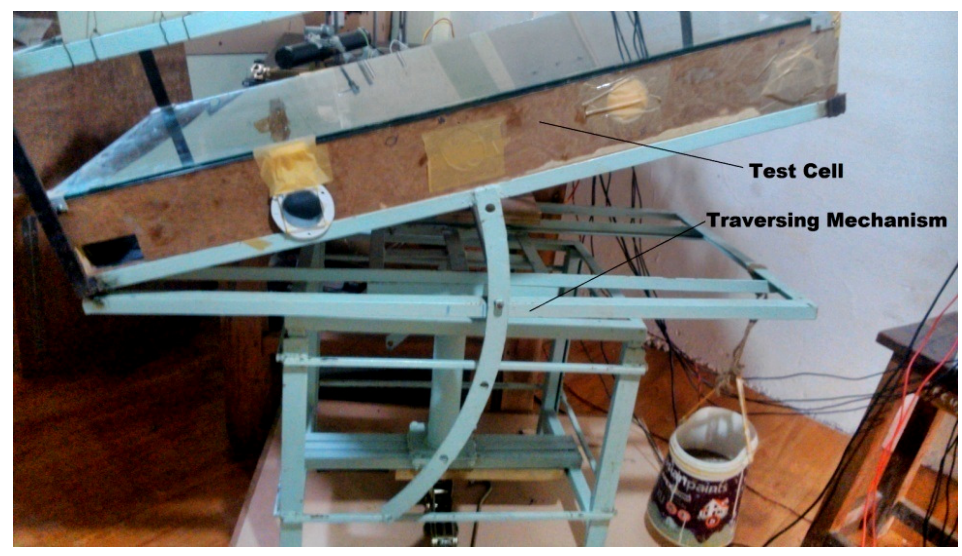

Figure1. Experimental test set up

A traversing stand type mechanism of 1 inch sized mild steel angles has also been designed and fabricated that can position the test cell during experimentation (Figure 1). This mechanism is designed to provide free movements to the test cell in vertical direction with a simple screw jack and also to revolve it about vertical and horizontal axes. In this way the test cell can be adjusted against laser beam. A $10 \mathrm{~mW}$ He-Ne laser gun (Figure 3) is set firmly on horizontal table surface near one of the optical windows and can be moved parallel to the normal axis of the test cell with screw and nut arrangement. Laser gun projects beam of $1.5 \mathrm{~mm}$ diameter through the test cell. Five (RTD type PT-100; $0.1^{\circ} \mathrm{C}$ resolutions) temperature sensors are fitted inside the test cell $35 \mathrm{~cm}$ away from the inlet ports in a central normal axis at positions of $0 \mathrm{~mm}, 10 \mathrm{~mm}, 40 \mathrm{~mm}$, $70 \mathrm{~mm}$ and $100 \mathrm{~mm}$ above the absorber surface (base) (Figure 4a). Inlet and outlet air temperatures are measured by K- type thermocouples. Thermal gradient profiles computed by optical method have been compared with similar results given by RTD (PT-100) temperature sensors for validation of optical method. 


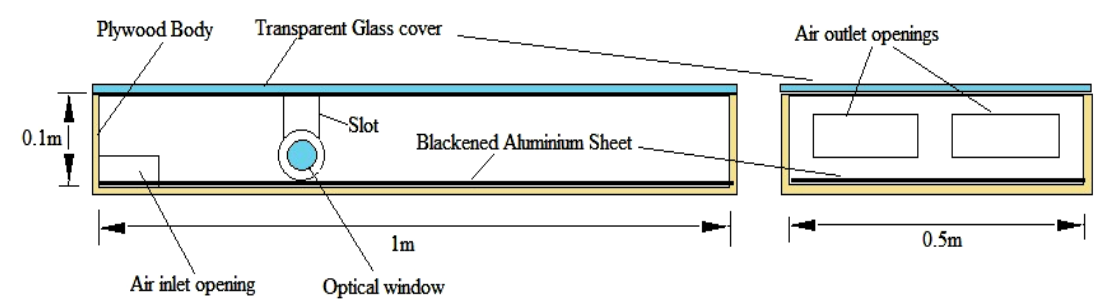

(a)

(b)

Figure2. Schematic views of solar air heater (test-cell) (a) Front view (b) Side View

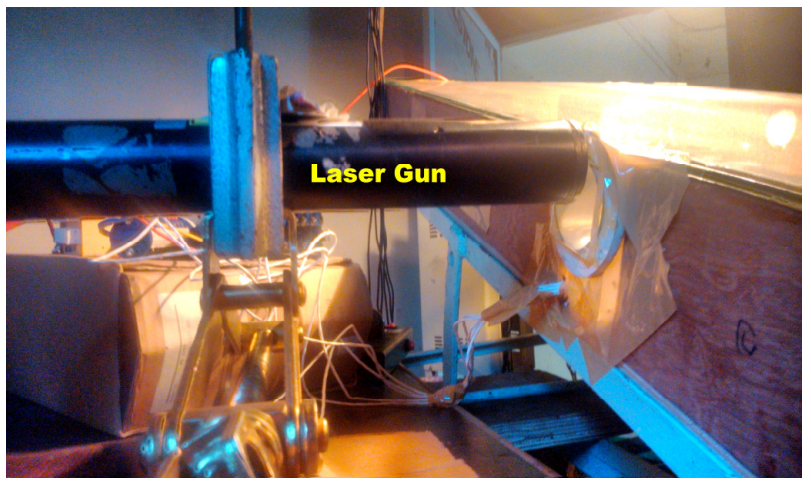

Figure 3. 10mW He-Ne laser gun projecting laser through test cell

A tool room micrometer of $0.01 \mathrm{~mm}$ least count and white hard and smooth paper screen are fitted over optical window (Figure 4b) on opposite side of laser gun for minutely measurement of laser beam deviation during experimentation. For artificial solar radiation, six halogen lamps; of $1000 \mathrm{~W}$ (three in numbers) and 500W (three in numbers) arranged in zig-zag manner (Arrangement is depicted in figure 5) have been fitted on a steel frame welded with traversing mechanism as shown in figure 6. The reasons for using lamps of two intensities in the laboratory are to achieve adequate intensity of radiation and to have better control for variation in the intensity. A variable electrical supply $(220$ Volts, $50 \mathrm{~Hz}, \mathrm{AC})$ is provided through an autotransformer control (provides variation in output voltage from 0 to 220 volts) to halogen lamps for varying radiation intensity. Pyranometer is used to calibrate artificial solar radiation for natural solar radiation intensity. 
International Journal of Recent advances in Mechanical Engineering (IJMECH) Vol.4, No.3, August 2015

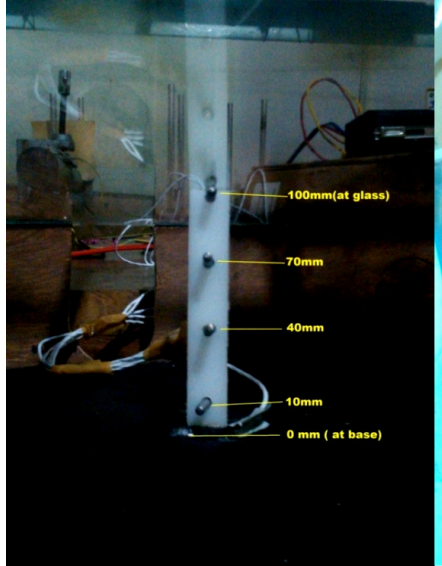

(a)

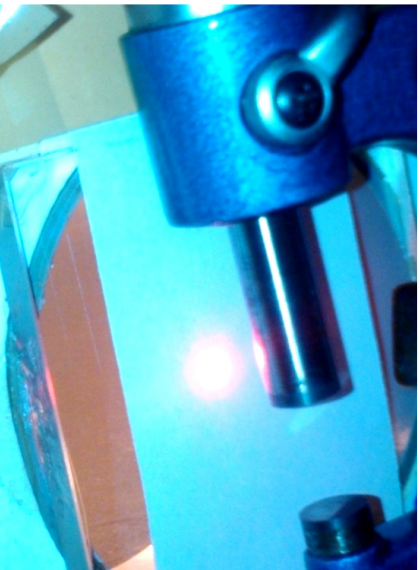

(b)

Figure 4( $\mathrm{a}$ and $\mathrm{b})$. PT-100 thermal sensors and micrometer

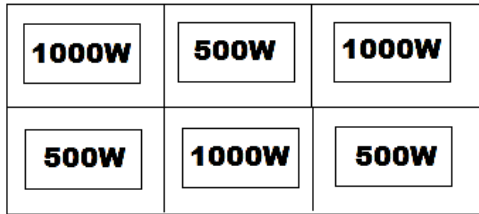

Figure5. Arrangement of halogen lamps

Halogen lamp frame is maintained parallel to transparent cover of test cell to ensure normal incidence of radiation on test cell during experimentation. The distance between test cell top cover and halogen lamps frame is kept constant as $18 \mathrm{~cm}$.

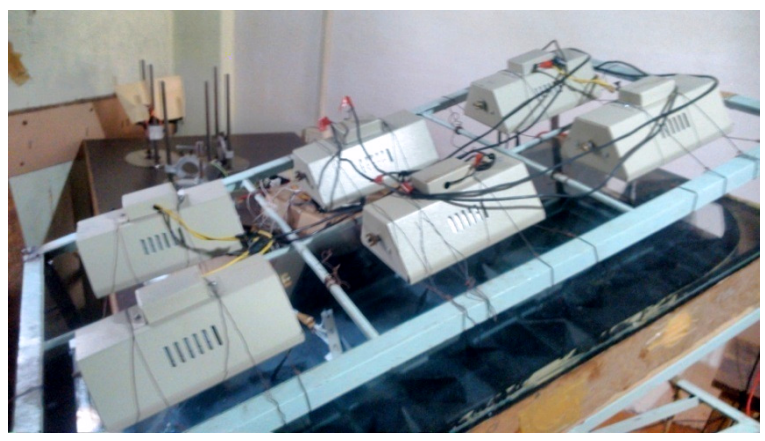

Figure6. Halogen lamps for artificial solar radiation 


\section{DAta REDUCTION}

\subsection{Fundamentals of Optical Beam Deviation method}

Authors have used following fundamentals in their investigation work.

$$
q=h\left(T_{s}-T_{a}\right)
$$

Where,

$h=$ Coefficient of convective heat transfer between air and vertical surface

$T_{s}=$ surface temperature

$T_{a}=$ ambient air temperature

The heat flux can also be given by the Fourier law of heat conduction as considered system is in steady state.

$$
q=-k \frac{d T}{d y}
$$

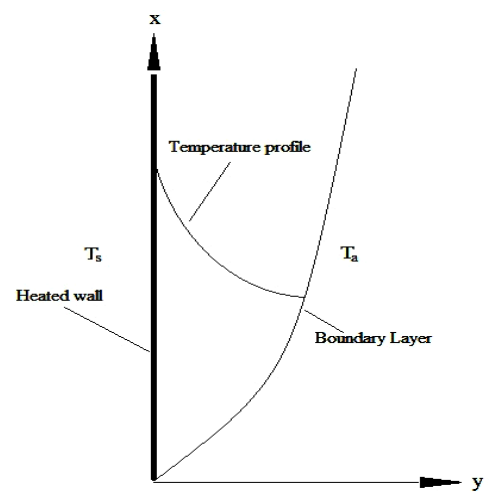

Figure7. Temperature profile near heating vertical surface

Where, $\frac{d T}{d Y}$ is rate of temperature change with respect to $\mathrm{y}$-axis and $k$ is thermal conductivity of flowing air.

From equations (2) and (3) the expression of convective heat transfer coefficient can be given as.

$$
h=\frac{-k \frac{d T}{d y}}{\left(T_{s}-T_{a}\right)}
$$

The relation between air density and refractive index is described by the Lorenz-Lorentz law.

$$
\left(\frac{n^{2}-1}{n^{2}+1}\right) \frac{1}{\rho}=\frac{N}{M}=\text { Constant }
$$


Where: $n$ is the refractive index of air, $\rho$ is the mass density of air $\left[\mathrm{kg} / \mathrm{m}^{3}\right], N$ is the molar refraction of $\operatorname{air}\left[\mathrm{m}^{3} / \mathrm{mol}\right], M$ is the molar mass of air $[\mathrm{g} / \mathrm{mol}]$.

The refractive index of air at a given wavelength is also dependent on the mass density of air.

$$
n=f(\rho)
$$

Air is considered to behave as perfect gas at atmospheric pressure and in the temperature range of $300-400 \mathrm{~K}$. The relation among mass density of air and its temperature is given by the state equation.

$$
\frac{p V}{T}=R \text { i.e. } \rho=\frac{p M}{R T}
$$

Where, $p$ is the pressure of air $[\mathrm{Pa}], T$ is the absolute temperature of air $[\mathrm{K}], V$ is the molar volume of air $\left[\mathrm{m}^{3} / \mathrm{mol}\right]$ and $R$ is the universal gas constant $[\mathrm{J} / \mathrm{kgmol} . \mathrm{K}]$. With assuming isobaric condition, the change in mass density of air is inversely proportional to the temperature change, and thus the refractive index variation is proportional to the air temperature change.

$$
\left(\frac{n_{o}-1}{n-1}\right)=\frac{\rho_{o}}{\rho}=\frac{T}{T_{o}}
$$

Where, $n_{o}, \rho_{o}$ and $T_{0}$ are refractive index, density of air at $0^{\circ} \mathrm{C}$ and its temperature.

For air a constant is defined for its refractive index change with respect to temperature for $650 \mathrm{~nm}$ wavelength laser beam at the temperature of $300 \mathrm{~K}$. This is given by B. Gebhart et al. [15] as

$$
\frac{d n}{d T}=0.961 \times 10^{-6}
$$

Then, the expression between the refractive index gradients and temperature gradients can be derived as

$$
\frac{d T}{d y}=\frac{1}{0.961 \times 10^{-6}} \frac{d n}{d y}
$$

Assuming uniform refractive index along the path of laser beam propagation and appropriate geometrical conditions, an expression for optical beam deviation comes out to be as follows.

$$
\frac{d n}{d y}=\frac{2 n_{o} \Delta y}{L^{2}}
$$

Where, $L$ is net laser beam path length, $n_{0}$ is 1.0 for air, $\Delta y$ is the measured laser beam deviation. Now, the temperature gradient can be evaluated by measuring laser beam deviation in a thermal field and using equations (10) and (11). 


\section{RESULT AND DISCUSSION}

\subsection{Solar Air Heater (with plane absorber under natural convection)}

For simplification purpose, solar air heater with plane absorber surface is termed as basic design of test cell in this present work. Experimental work was commenced with a testing the basic design with solar radiation intensity of $600 \mathrm{~W} / \mathrm{m}^{2}$ In In present work, solar air heater with plane absorber surface is defined as basic design of test cell. Experimental work gets started with a test on the basic design of solar air heater with solar radiation intensity of $600 \mathrm{~W} / \mathrm{m}^{2}$ and inclination of $30^{\circ}$ under natural convection mode. Thermal performance of test cell has been observed with variation in air mass flow rate by changing air outlet opening area (from $0.0511 \mathrm{~m}^{2}$ to $0.00146 \mathrm{~m}^{2}$ ) with a shutter. All the observations were taken in steady state condition, which was established by ensuring negligible variation in air outlet temperature. It has been reported that the thermal transients in flow field of the test cell takes approximately 75 minutes to die down and in reducing to steady state heat transfer condition. Readings displayed by K-type thermo couples and RTD-PT-100 sensors have been recorded conventionally. Overall thermal efficiency variation with temperature rise by varying air mass flow rate was recorded for constant solar radiation intensity of $600 \mathrm{~W} / \mathrm{m}^{2}$ (Table 1). The computation of overall thermal efficiency is performed using equation (1). Velocity of air is measured by anemometer of $0.1 \mathrm{~m} / \mathrm{sec}$ resolution at outlet ports and mass density of air (for calculating its mass flow rate) is picked at air outlet temperature from air property standards with assuming steady flow through test cell.

Table 1 Overall thermal efficiency and air mass flow rate

\begin{tabular}{|c|c|c|c|}
\hline $\begin{array}{c}\text { Air mass flow rate } \\
(\mathrm{gm} / \mathrm{sec} .)\end{array}$ & $\begin{array}{c}\text { Temperature rise } \\
\left(T_{o}-T_{i}\right)^{\circ} \mathrm{C}\end{array}$ & Outlet area $\left(\mathbf{m}^{2}\right)$ & Thermal Efficiency \% \\
\hline 0.695 & 30 & 0.0065 & 6.99 \\
\hline 0.7428 & 27 & 0.00146 & 6.72 \\
\hline 0.784 & 29 & 0.0073 & 7.62 \\
\hline 0.937 & 31 & 0.00438 & 9.74 \\
\hline 0.946 & 27 & 0.00876 & 8.56 \\
\hline 1.093 & 30 & 0.0511 & 10.99 \\
\hline 1.113 & 27 & 0.01022 & 10.07 \\
\hline 1.257 & 30 & 0.0058 & 12.57 \\
\hline 1.261 & 28 & 0.01168 & 11.8 \\
\hline 1.39 & 32 & 0.01314 & 14.91 \\
\hline
\end{tabular}

In this experiment, it has been observed (Table 1) that overall thermal efficiency rises with air mass flow rate and it becomes maximum $\left(14.91 \%\right.$ ) at flow rate of $1.39 \mathrm{gm} / \mathrm{sec}$ and $0.01314 \mathrm{~m}^{2}$ outlet opening area with attaining temperature rise of $32^{\circ} \mathrm{C}$. Further change in air mass flow rate by shutter operation was not possible in the present configuration. This value of overall thermal efficiency has therefore been considered as benchmark for further parts of investigation on this apparatus. Variation in thermal gradient parallel to the normal axis of test cell at a distance of $31 \mathrm{~cm}$ from the inlet air openings was determined using laser beam deviation method and on the basis of eq. 9, 10 and 11. Laser beam path length (L) is $527 \mathrm{~mm}$ (width $500 \mathrm{~mm}+$ average of wall and window thicknesses $27 \mathrm{~mm}$ ). Initial readings of tool room micrometer are carefully recorded for centre of beam projection on white paper screen at interval of $5 \mathrm{~mm}$ from the base in off radiation condition. Similarly, final readings are taken under steady state heating condition. The differences between final and initial readings have given the values of laser beam deviations. RTD (PT-100) thermal sensors have also provided thermal gradient variations near the laser beam 
line at a distance of $35 \mathrm{~cm}$ from the inlet air openings. Thermal gradient in the direction of laser beam propagation is assumed to be negligible. The representations of thermal gradient profiles determined by laser beam deviation method and thermal sensors are shown in figures 8 and 9 respectively.

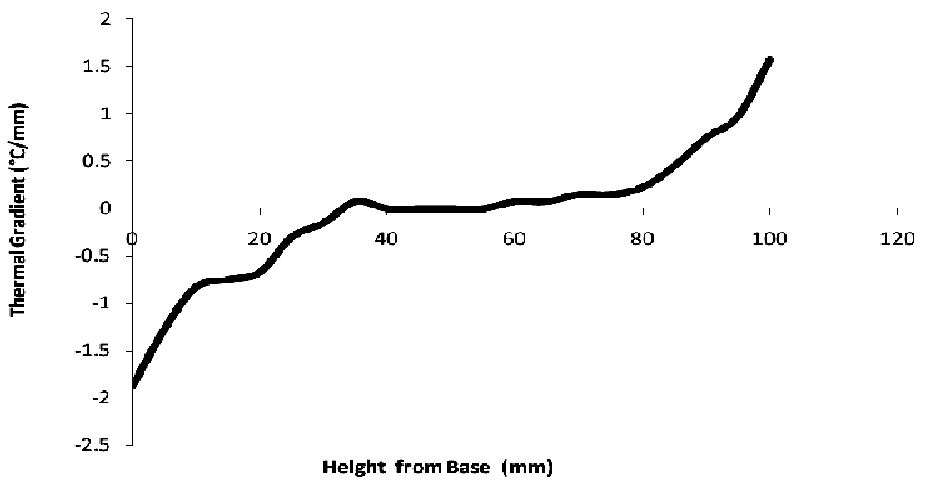

Figure8. Thermal gradient profile of basic design of solar air heater at solar intensity of $600 \mathrm{~W} / \mathrm{m}^{2}$ (laser beam deviation method)

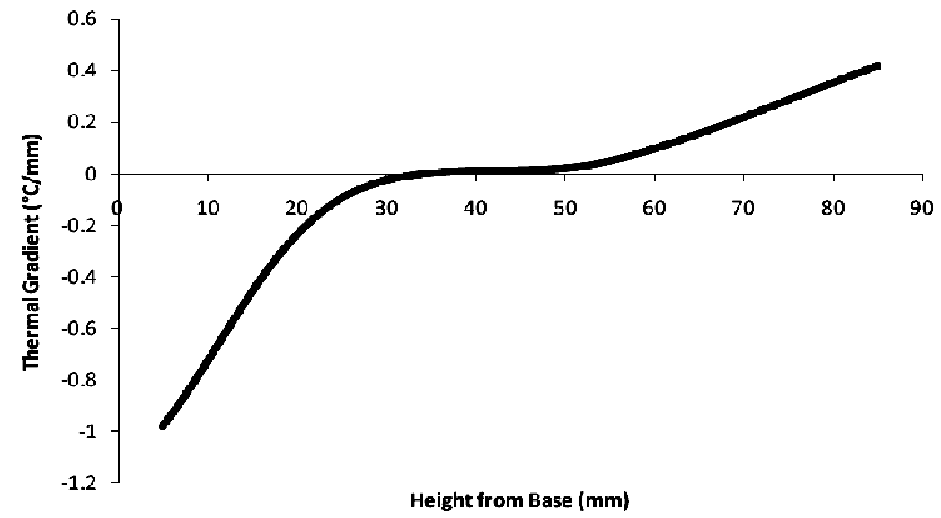

Figure9. Thermal gradient profile of basic design of solar air heater at solar intensity of $600 \mathrm{~W} / \mathrm{m}^{2}$ (by thermal sensors)

laser beam deviation method, thermal gradients for total width of test cell is computed, while in second method thermal gradients for a single normal axis in total width of the thermal flow field is calculated. In other way, it can be stated that, optically computed values of thermal gradients are line averages of thermal gradients for a position of laser beam for total width and it is localised in case of measurement method. Secondly, in the laser beam deviation method thermal gradients are determined at step size of $5 \mathrm{~mm}$ above the base in scanning of total $100 \mathrm{~mm}$ height. In this way, there are twenty one values for total $100 \mathrm{~mm}$ height. On the other hand thermal sensors could record only four values. These factors may be behind the difference in thermal gradient profiles obtained by laser beam deviation and thermal sensors. However, both values suggest that thermal gradient changes its nature at central portion of thermal flow field. It shows thermal gradient is having zero values around central portion (between $25 \mathrm{~mm}$ and $50 \mathrm{~mm}$ heights). This clearly indicates that temperature is decreasing from absorber base surface towards centre line and increasing from centre towards top glass cover and reporting the thermal flow field in central portion to be convection dominated and which can acts as regime near boundaries of the field. A mean temperature difference of around $13.3^{\circ} \mathrm{C}$ between centreline and boundary 
surfaces has been noticed. This shows that there is poor rate of heat transfer between air and boundary surfaces. This can be improved by bringing more uniform temperature distribution (almost zero thermal gradients) along normal axis of solar air heater. This point has been taken in consideration in next section (5.2) and conducting porous medium is incorporated between boundaries of thermal flow field.

\subsection{Inclined V-porous ribs with conducting side walls under natural convection}

are set inclined to each other at right angle. The inclined arrangement is chosen to maximize the portion of air mass flow through the mesh which in turn can increase heat absorption from porous medium. Matrix is of aluminium wire net (chosen owing to high thermal conductivity) having square openings of $2 \mathrm{~mm} \times 2 \mathrm{~mm}$, while net thickness is $0.95 \mathrm{~mm}$. Width of each rib is taken as 8 $\mathrm{cm}$. A space of $22 \mathrm{~cm}$ is given between first two ribs from inlet side for uninterrupted projection of laser beam and to mount thermal sensors.

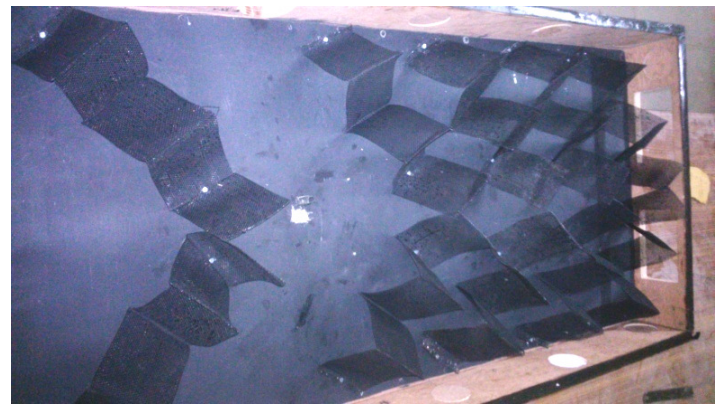

Figure10. Solar air heater with inclined V-porous ribs

Unlike last experiment, where side walls of test cell were made non- conducting/adiabatic (wooden surface) here the side wall surfaces have been covered by blackened aluminium sheet in order to increase the contribution of side walls in heat exchanging process (Figure 11). Shorter side wall on outlet side remained uncovered due to its low surface area. These sheets are made slightly curved on base side in order to increase radiation absorbing area and to create smooth air flow in corners. In order to create turbulence in the flow stream a triangular baffle in sheet (Figure 12) was placed in between inlet openings while entering the heater and allowing air stream to move in longitudinal direction.

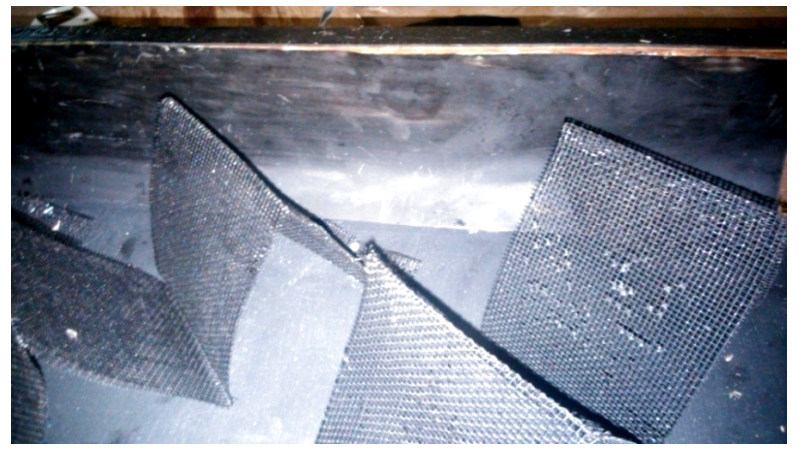

Figure11. Aluminium made conducting side walls (curved on base side) 
International Journal of Recent advances in Mechanical Engineering (IJMECH) Vol.4, No.3, August 2015

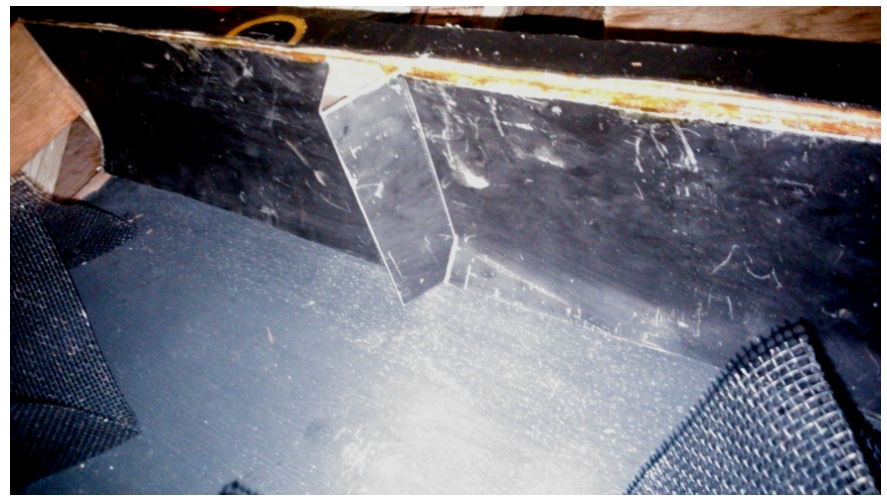

Figure12. Triangular baffle between inlet openings

For streamlining the air flow in outlet side corners and to avoid stagnation in flow the sheet has been given a curvilinear bending as shown in figure 13 .

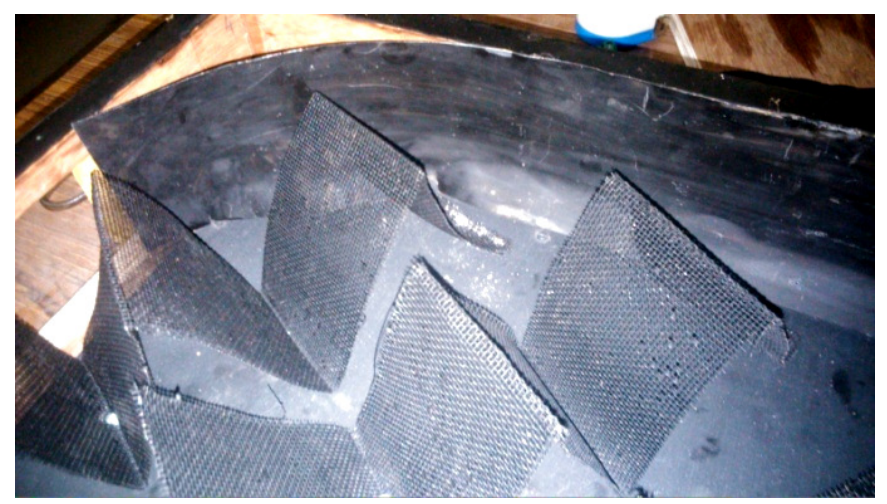

Figure13. Curvilinear bend at outlet

found to be $19.93 \%$ (a percentage increment of $33.66 \%$ ) with this modification in the design. reduced to $7.3^{\circ} \mathrm{C}$ from $13.3^{\circ} \mathrm{C}$ and a significant drop in thermal gradients at boundaries is noticed in both the approaches. The other advantage is seen in terms of enlargement in convection dominate zone from $25 \mathrm{~mm}$ to $60 \mathrm{~mm}$ in optical measured results; to $40 \mathrm{~mm}$ in measured results when compared with results of section 5.1.

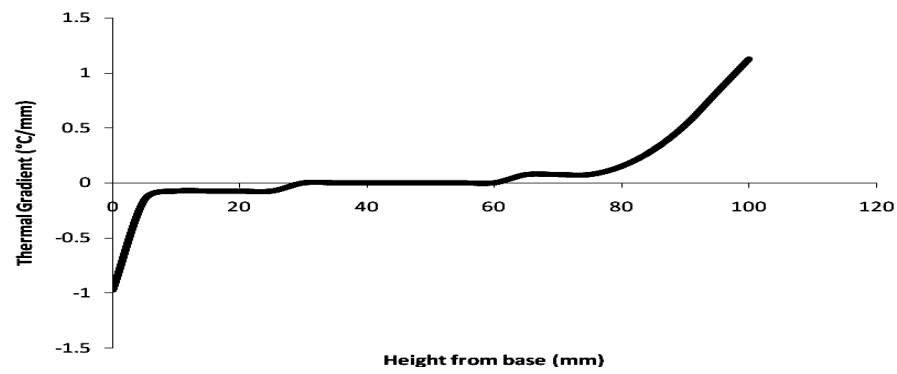


Figure14. Thermal gradient profile of solar air heater with inclined V-porous ribs and conducting side walls at solar intensity of $600 \mathrm{~W} / \mathrm{m}^{2}$ (laser beam deviation method).

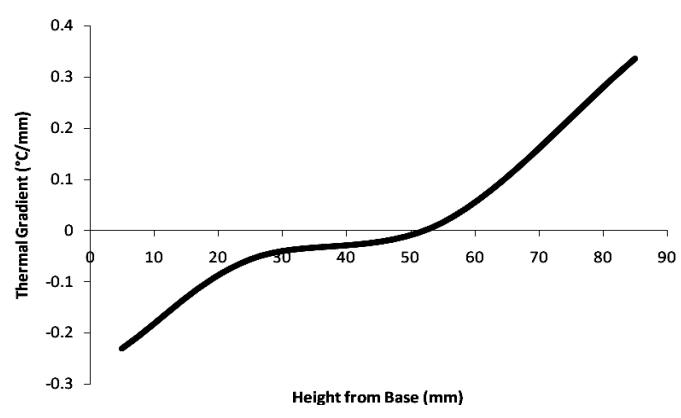

Figure15. Thermal gradient profile of solar air heater with inclined V-porous ribs and conducting side walls at solar intensity of $600 \mathrm{~W} / \mathrm{m}^{2}$ (thermal sensors).

and intensification of turbulence in the thermal flow field. And, this has been achieved by inclusion of inclined $\mathrm{V}$-porous ribs and conducting side wall in the solar air heater.

\subsection{Inclined V-porous ribs with conducting side walls under forced convection}

A little improvement in performance has been achieved in design optimization testing of solar air heater under natural convection mode. The attained air mass flow rates are on lower side that resulted in small improvement in the efficiency of solar air heater. However, significant changes in the temperature distribution and thermal gradient were observed. More improvement in thermal performance is possible, if additional efforts are applied to reduce thermal gradient or to attain more uniform temperature distribution along normal axis of the heater. This can be executed by inducing turbulence in flow field that increases velocity of fluid flow in the heater. But in natural convection mode there is limitation of velocity which could be attained. Therefore, forced convection mode has been considered to be applied in testing. A pair of small sized axial flow exhaust fans was fitted in the outlet side of openings (Figure 16) which throws hot air from the heater and to produce induced draught inside it. Exhaust fans are $80 \mathrm{~mm}$ in diameter, each having seven blades and run by 12 volt DC supply. Power supply to fans is through voltage dimmer so to vary the fan speeds and to put variation in outlet velocity thus changing the mass flow rate. Fans can be run at five different speeds.

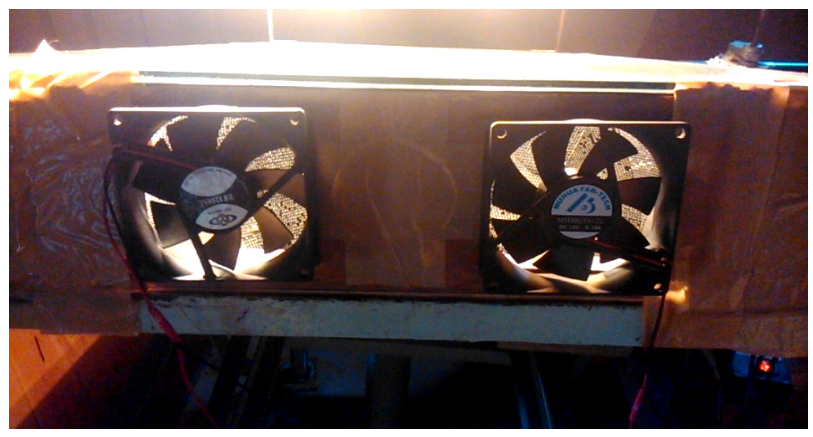

Figure16. Exhaust fans placed on outlet side for achieving forced convection mode 
Keeping other parameters same as discussed in sections 5.1 and 5.2 results for overall thermal efficiency and thermal gradient has been obtained for air outlet velocity of $0.5 \mathrm{~m} / \mathrm{sec}$ and mass flow rate of $2.42 \mathrm{gm} / \mathrm{sec}$. Outlet opening area has now been reduced due to fan fittings to $0.0047 \mathrm{~m}^{2}$ from previous value of $0.01314 \mathrm{~m}^{2}$. All the observations and computations have been performed in the same manner as in natural convection mode. Average temperature rise for air in steady state condition has reached $39^{\circ} \mathrm{C}$ and, mean value of overall thermal efficiency was found as $31.6 \%$ (11.67\% higher than previous case). Variation in thermal gradient along normal was recorded optically and though thermal sensors and are presented in figures (17) and (18) respectively.

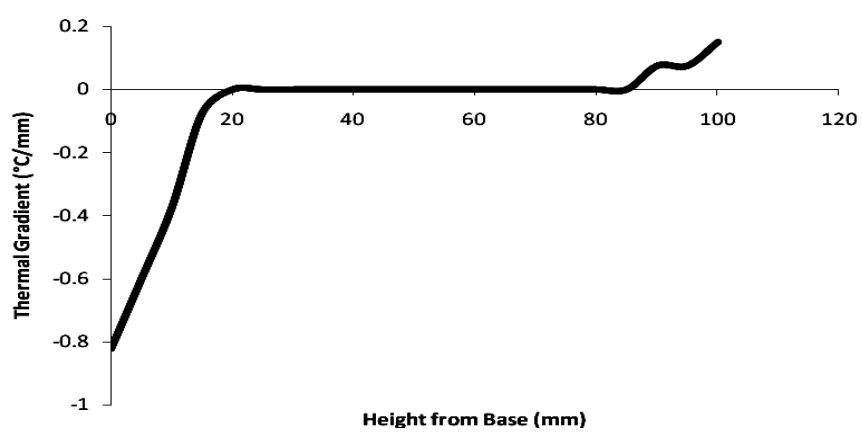

Figure 17. Thermal gradient profile of solar air heater under forced convection at solar intensity of $600 \mathrm{~W} / \mathrm{m}^{2}$ and $2.42 \mathrm{gm} / \mathrm{sec}$ (laser beam deviation method).

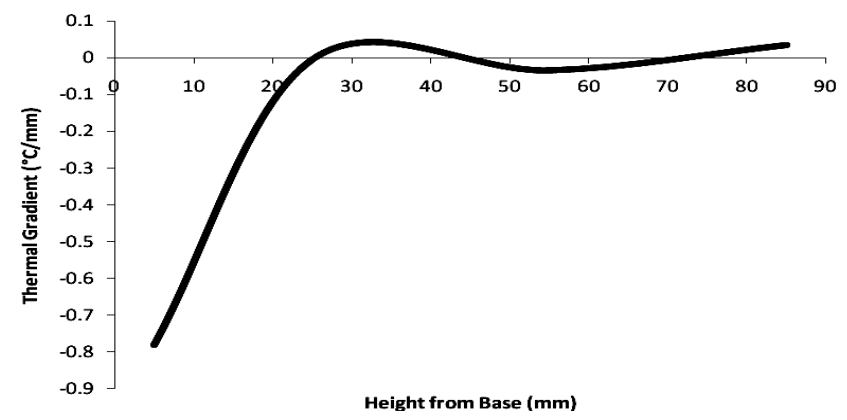

Figure 18. Thermal gradient profile of solar air heater under forced convection at solar intensity of $600 \mathrm{~W} / \mathrm{m}^{2}$ and $2.42 \mathrm{gm} / \mathrm{sec}$ (thermal sensors).

The explanation for increase in overall thermal efficiency is as follows. In forced convection testing span of positive thermal gradient has shortened resulting in elongated convection dominated zone (zero thermal gradients area) as seen in above graphical representations. It is nearly of $80 \mathrm{~mm}$ and $65 \mathrm{~mm}$ in optical and measured results respectively. A significant fall in thermal gradient on glass cover side has also been observed. This is an indication of increased rate of heat transfer between air and glass cover end and reduction in top cover thermal losses, results in higher thermal efficiency. 


\section{CONCLuSiON}

Experimental test set up at laboratory scale was designed and developed for thermal performance testing of flat plate solar air heater under artificial and constant solar radiation intensity of $600 \mathrm{~W} / \mathrm{m}^{2}$ with $30^{\circ}$ inclination. For test cell a solar An experimental test set up at laboratory scale has been developed for thermal performance testing of flat plate solar air heater with constant solar radiation intensity of $600 \mathrm{~W} / \mathrm{m}^{2}$ and at $30^{\circ}$ inclination. A solar air heater of size $1 \mathrm{~m} \mathrm{x} 0.5 \mathrm{~m} \mathrm{x}$ $0.1 \mathrm{~m}$ has been designed and fabricated. Three configurations of experimental test set up namely (i) plane absorber (basic design) under natural convection (ii) inclined V-porous ribs with conducting side walls under natural convection and (iii) inclined V-porous ribs with conducting side walls under forced convection have been tested. All the experiments were conducted with artificial and calibrated solar radiation. Performances of these designs have been analysed on the basis of thermal efficiency and thermal gradient in normal to the base $31 \mathrm{~cm}$ away from inlet ports of the solar air heater. Considering outcomes of experimentation work performed on three configurations of experimental test set up, the following points can be concluded:

1. An increase of $16.69 \%$ in overall thermal efficiency of solar air heater is achieved with respect to the basic design of solar air heater.

2. It is observed that, thermal gradient along normal axis of solar air heater plays an effective part in its thermal performance.

3. Span of convection dominated zone in thermal flow field is an important parameter in uniform distribution of temperature along the normal to the absorber surface.

4. Inclusion of porous conducting medium increases rate of heat transfer between air and absorber surface.

5. Employing forced convection can increase thermal performance of solar air heater as it intensifies turbulence and increases mass flow rate.

\section{LIMITATIONS AND FUTURE SCOPE}

In this experimental research work solar air heater (test cell) is tested at artificial and constant solar radiation intensity. The actual thermal performance under variable natural solar radiation may vary from findings of this investigation. Also, In this experimental research work solar air heater (test cell) is tested at artificial and constant solar radiation intensity. The actual thermal performance under variable natural solar radiation may vary from findings of this investigation. Also, wind effect is not included in indoor testing method. In spite of these limitations indoor testing of solar air heater at laboratory scale provides tools for critically testing under steady state heat transfer condition which is not possible with natural environment. Secondly, there is scope of testing at various solar radiation intensities and air mass flow rates. Non-intrusive optical measurement testing is also found quite validated by direct measurement technique. There is scope of extending experimental work by testing at other values of solar radiation intensities and thermal gradient measurement for entire volume of solar air heater.

\section{ACKNOWLEDGEMENT}

Authors acknowledge Madhya Pradesh Council of Science and Technology (MPCST), Bhopal gratefully for financial support to the research work. 


\section{REFERENCES}

[1] Moummi N., Youcef-Ali S., Moummi A. and Desmons J.Y., (2004) "Energy analysis of a solar air collector with rows of fins". Renewable Energy., Vol.29, pp 2053-2064.

[2] Karim M.A. and Hawlader M.N.A., (2004) "Development of solar air collectors for drying applications" Energy Conversion and Management, 45, pp 329-344.

[3] Chabane Foued, Moummi Noureddine , Benramache Said, Bensahal Djamel, Belahssen Okba and Lemmadi Fatima Z. ,(2013) "Thermal Performance Optimization of A Flat Plate Solar Air Heater" International Journal of Energy \& Technology, Vol.5, No. 8, pp 1-6.

[4] Karwa Rajendra, Panwar O. P. and Maheshwari B.K.,(2010) "Performance Study of a Solar Air Heater with Chamfered Rib-roughness on Absorber Plate for Space Heating Applications", Proceedings 20th National And 9th International ISHMT-ASME Heat And Mass Transfer Conference, No.130, pp 463-470.

[5] Hans Vishavjee Singh, Saini R.P. and Saini J.S., (2010) "Experimental investigation of heat transfer and friction characteristics of a multiple V-rib roughened solar air heater" Proceedings 20th National and 9th International ISHMT-ASME Heat and Mass Transfer conference, No.152, pp 546-551.

[6] Chand Prabha and Sharma S.P., (2010) "Thermal Performance Prediction Of Extended Absorber Solar Air Heater" Proceedings 20th National and 9th ISHMT-ASME Heat and Mass Transfer conference, No.289, pp 1120-1124.

[7] Koyuncu Turhan, (2006) "Performance of various design of solar air heaters for crop drying applications" Renewable Energy, Vol.31, pp 1073-1088.

[8] Esen Hikmet,(2008) "Experimental energy and exergy analysis of a double-flow solar air heater having different obstacles on absorber plates" Building and Environment, Vol.43, pp $\quad$ 10461054.

[9] Chabane Foued, Moummi Noureddine and Benramache Said,(2013) "Experimental analysis on thermal performance of a solar air collector with longitudinal fins in a region of Biskra, Algeria" Journal of Power Technologies, Vol.93 (1), pp 52-58.

[10] Venu Arun and Arun P., (2013) “Simulation Studies on Porous Medium Integrated Dual Purpose Solar Collector" International Journal of Renewable Energy Research, Vol.3 No.1, pp 114-120.

[11] Romdhane Ben Slama, (2007) "The air solar collectors: Comparative study, introduction of baffles to favor the heat transfer" Solar Energy, Vol.81, pp 139-149.

[12] Garg H. P. and Prakash J., 2012. Text-Book, "Solar Energy Fundamentals and Applications" Published by Tata McGraw Hill Education private Limited, first revised edition.

[13] Solanki S.C., Dubey Swapnil, and Tiwari Arvind, (2009) “ Indoor simulation and testing of photovoltaic thermal (PV/T) air collectors” Applied Energy, Vol.86, pp 2421-2428.

[14] Mihalka Peter, Drzik Milan and Matiasovsky Peter,(2007) "Mesurement of Local Convective Surface Heat Transfer Coefficient by Photoelectric Method" Proceedings of Thermophysics, Bratislava, Vyadavatelstvo STU, ISBN-978-80-227-27465-4, pp 86-92.

[15] Gebhart B., Jaluria Y., Mahajan R.L. and Sammakia B., (1988) "Buoyancy-Induced Flows and Transport." Book, Hemisphere Publishing Corporation, New York.

\section{AUTHORS (SHORT BIOGRAPHY)}

\section{First Author}

\section{Santosh Vyas}

Associate Professor and Head.

Department of Mechanical Engineering,

Mahakal Institute of Technology and Science, Ujjain (MP), India

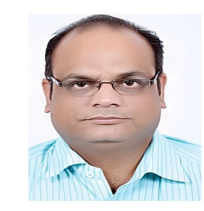

Registered for PhD in RGPV Bhopal Under the supervision of Dr. Sunil Punjabi, Associate Professor, UEC, Ujjain. Topic:- Design Optimization of Solar Dryer, (Work is approved and funded by MPCST, Bhopal ). 


\section{Professinal Experience}

Aug'1999-July 2000 Contract Lecturer, Department of Mechanical Engineering, Government Polytechnic, Jaora (MP)

Oct' 2001-July2007～Lecturer, Department of Mechanical Engineering, MIT, Ujjain (MP)

July 2007- March 2011 Reader, Department of Mechanical Engineering, MIT, Ujjain (MP)

April 2011-April 2012 Associate Professor, Department of Mechanical Engineering, AIT, Ujjain (MP)

April 2012-Janaury 2013 Associate Professor and Head, Department of Mechanical Engineering, Oriental University, Indore.

January 2013-Present Associate Professor and Head, Department of Mechanical Engineering, MITS Ujjain (MP).

\section{Research Experience}

Involved in engineering research work for last five years in the area of thermal and fluid engineering and application of research work is solar thermal systems. He has also got four research papers published in international and national journals and conferences.

\section{Second Author \\ Dr. Sunil Punjabi \\ Associate Professor \\ Department of Mechanical Engineering, \\ Ujjain Engineering College, Ujjain (MP) India}

$\mathrm{PhD}$ (Fluid and Thermal Engineering), from Department of Mechanical Engineering, Indian Institute of Technology, Kanpur, India. Topic: Experimental Study of Convection in Differentially Heated Fluid Layers using Laser Interferometry. Under the supervision of Dr. K. Murlidhar, Professor and Dean (R\&D), IIT Kanpur and Dr. P.K. Panigrahi, Professor, IIT Kanpur.

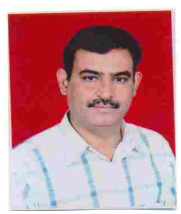

Post-Doctoral Fellow: Department of Fluid Mechanics and Heat Transfer, Faculty of Engineering, Tel Aviv University 69978 Tel Aviv, Israel. Research Field: Turbulent mixing layer around wind tunnels using optical instrumentation technique combined with hot wire anemometer. Advisers: Prof. E, Kit and Dr. Alexander Gelfgat.

Principal Investigator in Research Project of Madhya Pradesh Council of Science and Technology, Bhopal at Ujjain Engineering College, Ujjain.

Publications: More than 15 papers have been published in national and international conferences and journals.

Book Review work: Computerized Tomography for Scientists and Engineers ( Taylor and Francis (USA) and Anamaya (India).One chapter on Convection in differentially heated fluid layers and its reconstruction using radial tomography in an octagonal cavity.

\section{Keynote Lecture}

"Influence of layer height on a buoyancy-driven convection in differentially heated superimposed fluid layers confined in a rectangular cavity." $14^{\text {th }}$ international Conference on Computational and Experimental Engineering and Sciences, Miami, Florida, USA. 